\title{
Potentially Postbiotic-Containing Preservative to Extend the Use-By Date of Raw Chicken Sausages and Semifinished Chicken Products
}

\author{
Carolyne Luciane de Almeida Godoy ${ }^{1}$, Lucas Marques Costa ${ }^{2}$, Carlos Alberto Guerra ${ }^{2}$, \\ Vanessa Sales de Oliveira ${ }^{3}$, Breno Pereira de Paula ${ }^{4}$, Wilson José Fernandes Lemos Junior ${ }^{5}$, \\ Vinícius da Silva Duarte ${ }^{6}$ (D), Rosa Helena Luchese ${ }^{3}$, Ivonete Rossi Bautitz ${ }^{1}$ and André Fioravante Guerra ${ }^{4, *(\mathbb{D})}$
}

Citation: de Almeida Godoy, C.L.; Costa, L.M.; Guerra, C.A.; de Oliveira, V.S.; de Paula, B.P.; Lemos Junior, W.J.F.; da Silva Duarte, V.; Luchese, R.H.; Bautitz, I.R.; Guerra, A.F. Potentially Postbiotic-Containing Preservative to Extend the Use-By Date of Raw Chicken Sausages and Semifinished Chicken Products. Sustainability 2022, 14, 2646. https:// doi.org/10.3390/su14052646

Academic Editor: Eleni Iacovidou

Received: 31 December 2021

Accepted: 10 February 2022

Published: 24 February 2022

Publisher's Note: MDPI stays neutral with regard to jurisdictional claims in published maps and institutional affiliations.

Copyright: (C) 2022 by the authors. Licensee MDPI, Basel, Switzerland. This article is an open access article distributed under the terms and conditions of the Creative Commons Attribution (CC BY) license (https:// creativecommons.org/licenses/by/ $4.0 /)$.
1 Biotechnology Postgraduate Program, Sector of Palotina, Federal University of Paraná (UFPR), Palotina 85950-000, Brazil; carolyne.godoy@hotmail.com (C.L.d.A.G.); ivonete.rossi@ufpr.br (I.R.B.)

2 BRC Ingredientes Ltda., Rio Claro 13505-600, Brazil; lucas@brcingredientes.com.br (L.M.C.); guerra.2alimentos@gmail.com (C.A.G.)

3 Department of Food Technology, Federal Rural University of Rio de Janeiro, Seropedica 23897-970, Brazil; vanessasdo@bol.com.br (V.S.d.O.); rhluche@gmail.com (R.H.L.)

4 Departamento de Engenharia de Alimentos, Centro Federal de Educação Tecnologica Celso Suckow da Fonseca (CEFET/RJ), Valença 27600-000, Brazil; breno.paula@cefet-rj.br

5 Faculty of Science and Technology, Free University of Bolzano-Bozen, 39100 Bolzano, Italy; juniorjflemos@gmail.com

6 Faculty of Chemistry, Biotechnology and Food Science, Norwegian University of Life Sciences, P.O. Box 5003, N-1432 Ås, Norway; vs_duarte01@hotmail.com

* Correspondence: andre.guerra@cefet-rj.br or andrefioravanteguerra@gmail.com; Tel.: +55-21-991423932

\begin{abstract}
This study aimed to evaluate the use of potentially postbiotic-containing preservative (PPCP), produced in a semiculture fermentation system with Lacticaseibacillus paracasei DTA 83 and Saccharomyces cerevisiae var. boulardii 17 , to extend the use-by date of raw chicken sausages and semifinished chicken products. Microorganisms associated with the spoilage of chicken products were stimulated to grow by pair incubation of the products at two different temperatures and with collection at different times. The turbidity method was performed to evaluate the microbial susceptibility to PPCP. PPCP was added in chicken products to obtain an in situ partial inhibitory effect on spoilage microorganisms to extend the use-by date. The in vitro trial showed total inhibition of the microbial growth by adding above $3.0 \%$ of PPCP. Although this concentration showed a remarkable inhibitory potential, its addition can severely impact the formulation cost. Thus, the application of doses with partial microbial inhibition may be a suitable strategy for the use of PPCP in chicken products. The results revealed that cold chain management and couse of PPCP in chicken products extended the proposed use-by date, suggesting an alternative food preservation technology for the use of naturally derived compounds.
\end{abstract}

Keywords: biopreservative; biocontrol; metabiotic; beneficial; compounds

\section{Introduction}

The potential of microorganisms and/or their metabolic products to extend the shelf life and enhance the safety of foods dates back centuries [1]. While biocontrol of food using Generally Recognized as Safe (GRAS) microorganisms was already reported in the literature, studies concerning the use on industrial scale is still scarce $[2,3]$. The cost to purchase available biocins in the commerce is determinant to discourage the use [4]. As a result, food operators prefer chemically synthesized preservatives $[5,6]$. Thus, precultured medium with GRAS microorganisms may be a low-cost alternative regarding biopreservatives in foods. 
Raw meat, fresh poultry meat, and poultry products, such as raw chicken sausages and semifinished chicken products, are highly perishable foods due to their biological composition. Therefore, the high consumption of poultry products leads to concerns about product safety, shelf life, quality, and desirable sensory characteristics [7]. Regulatory agencies prescribe for "raw chicken or seasoned meat, cold or frozen stored" a microbiological limit that separates good quality from marginally acceptable quality ( $m=5 \log \mathrm{cfu} / \mathrm{g}$ ) [8-10]. Thus, the theory of barriers, as the use of preservatives to slow microbial growth, is often applied to extend shelf life.

Over the past decades as consumer awareness of the impact of food on health grew, alternative technologies for food preservation based on naturally derived compounds emerged. Lacticaseibacillus paracasei DTA 83 and Saccharomyces cerevisiae var. boulardii 17 were reported as candidate strains to deliver probiotics in food matrices. Moreover, probiotic strains were extensively used in the meat poultry chain, increasing consumers' interest in functional foods. The high capacity of probiotics to provide beneficial health effects in the host attracted scientific and commercial interests, highlighting microbial administration as a health-promoting strategy [11,12].

Some rigorous processes and analyses precede the commercialization of probioticcontaining functional foods to guarantee their safety for consumption [13]. However, there are also many restrictions related to the consumption of live microbes: systemic infections due to translocation, particularly in vulnerable patients such as pregnant and pediatric and geriatric populations, acquisition of antibiotic resistance gene, and interference with gut colonization in neonates $[14,15]$. Therefore, delivering probiotics to health-impaired individuals or when medical institutions are considered is still a matter of discussion. Indeed, the postbiotic effect derived from GRAS microorganisms can be safe in all circumstances. As a result, the production of products containing nonviable microorganisms or microbial cell extracts to provide beneficial effects in the host, such as probiotics, received considerable attention in recent years [16].

Postbiotic or synonymous, such as parabiotics, metabiotics, ghostbiotic, and heatinactivated microorganisms, refers to inactivated or produced compounds by microorganisms with a known chemical structure that can optimize host-specific physiological functions and regulate metabolic and/or behavior reactions connected with the activity of host natural microbiota $[17,18]$. To date, these terms were not endorsed by regulatory agencies; however, they were extensively studied and reported in the current literature [19-21].

In this background, this study aimed to produce potentially postbiotic-containing preservative (PPCP) in a semiculture fermentation system with L. paracasei DTA 83 and S. boulardii 17 to extend the use-by date of raw chicken sausages and semifinished chicken products. In addition, three logistic distribution routes $(\mathrm{R})$, including distribution centers (DC) and sale disposal of the products in the markets (M), were drafted to evaluate the impact of the cold chain management on the use-by date of the products.

\section{Materials and Methods}

\subsection{Method Design}

The products (raw chicken sausages and semifinished chicken products) were manufactured on industrial scale at a meat industry located in the state of Paraná, Brazil. The study was performed in two phases. During Phase 1, microorganisms associated with the spoilage of chicken products were collected after pair incubation of the products at lower $\left(3^{\circ} \mathrm{C}\right)$ and higher $\left(25^{\circ} \mathrm{C}\right)$ temperatures, with collection within four days. Different culture media were obtained from HiMedia (Mumbai, India). Brain-heart infusion (BHI), casoy, deMan, Rogosa, and Sharp (MRS), and yeast-peptone-dextrose extract (YPD) broth were used to collect major group of microorganisms, including Gram-positive and negative bacteria and yeasts. The susceptibility of the target microbiota to PPCP was assayed by turbidity method. During Phase 2, PPCP was produced on a pilot-industrial scale semicultured fermentation system and tested in situ in a controlled blind design, adding $1.0 \%$ and 1.5\% of PPCP. The standard formulation of each group was produced under the same conditions 
to serve as a control [22]. Five packages of each sample group (totaling 45 packages) were addressed to the laboratory for shelf-life validation. A durability study was performed by a microbial growth predictor, named MicroLab_ShelfLife ${ }^{\circledR}$ (Appendix A), under a realistic temperature profile recorded by an electronic device in three $\mathrm{R}$, totaling 27 simulations. Borderline of $5 \log \mathrm{cfu} / \mathrm{g}$ was entered in the predictive modeling to indicate the use-by date of the products according to regulatory agencies [8-10].

\subsection{Microbial Collection}

L. paracasei DTA 83 was isolated from stools of infants aged two weeks old at Rio de Janeiro (Brazil) in selective modified MRS agar medium (Lawvab) [23]. A protocol of Fernandes Figueira Institute (FIOCRUZ) was rigorously applied to collect and transport the samples. The strain was firstly identified by sequencing of the $16 \mathrm{~S}$ rDNA. Then, the complete genome was drafted and deposited in GenBank under the accession number QRBH00000000, [23-25]. L. paracasei DTA 83 was classified as a candidate probiotic by in vitro and in vivo trials [26,27]. This strain was considered to carry out food bioprocesses as reported by Guerra et al., Silva et al., and Oliveira et al. $[23,28,29]$. S. boulardii 17 (FLORATIL-200, Merck, France) was acquired as freeze-dried culture sachets.

The cultures were registered in the self-declared system of the Brazilian genetic heritage (SISGEN): L. paracasei DTA 83 and S. boulardii 17 (FLORATIL-200, Merck, Paris, France).

\subsection{PPCP Production}

PPCP was produced in a semiseparated coculture system at BRC Ingredientes Ltd.a, located in the state of São Paulo, Brazil. L. paracasei DTA 83 and S. boulardii 17 cultures were thawed at $7{ }^{\circ} \mathrm{C}$ for approximately $4 \mathrm{~h}$ and centrifuged at $6000 \times g$ for $5 \mathrm{~min}(2 \mathrm{~K} 15$, Sigma Laborzentrifugen, Osterode am Harz, Germany) for pellet separation. The liquid fraction (culture medium and glycerol) was discarded. Then, the remaining cell pellet was reconstituted with MRS or YPD, followed by overnight incubation at 36 and $30{ }^{\circ} \mathrm{C}$ for the growth of L. paracasei DTA 83 and S. boulardii 17, respectively. To obtain sufficient biomass to produce PPCP on a pilot-industrial scale, the cultures were scaled up $1 / 10(v / v)$ in axenic cultivation in a sterile culture medium with $0.05 \mathrm{M}$ soy protein, $0.1 \mathrm{M}$ glucose, and $0.005 \mathrm{M}$ phosphate. A cylindrical bioreactor ( $300 \mathrm{~L})$, made of stainless steel equipped with a stirring system and with a domed top and bottom, was used to produce PPCP. About $70 \%$ of the nominal capacity of the vessel was loaded with culture medium under a slight agitation (about $84 \mathrm{rpm}$ ) performed axially using a mechanical stirrer with a four-blade propeller ( $50 \times 15 \mathrm{~mm}$, length $\times$ width) and a $45^{\circ}$ pitch coupled to the bioreactor. The heat treatment $\left(75{ }^{\circ} \mathrm{C} / 2 \mathrm{~h}\right)$ was carried out by the electrical activation of three resistors $(3 \mathrm{kw})$, which were equidistant installed around the circumference of the vessel and positioned at $\frac{1}{4}$ the height of the tank bottom. After that, the temperature was reduced to $36^{\circ} \mathrm{C}$ by adding $20 \mathrm{~kg}$ of drinking ice. Semi-separated co-culture system was performed by inoculating L. paracasei DTA 83 to obtain a final cell concentration of ca. $7 \log \mathrm{cfu} / \mathrm{mL}$. After $30 \mathrm{~h}$, the $\mathrm{pH}$ decreased to around 4.8 and the temperature of the medium was reduced to $30^{\circ} \mathrm{C}$ at a rate of $0.5^{\circ} \mathrm{C} / \mathrm{min}$. Then, $\mathrm{S}$. boulardii 17 was inoculated to obtain a final cell concentration of ca. $6.0 \log \mathrm{cfu} / \mathrm{mL}$. After three days of fermentation coupled with $\mathrm{pH}$ decay to around 4.0 , the product was heated at $90^{\circ} \mathrm{C}$ for $10 \mathrm{~min}$ (heating rate of $1.2{ }^{\circ} \mathrm{C}$ for minute) to obtain PPCP. Variables such as $\mathrm{pH}$ and temperature were continuously monitored over the process by a portable digital pH meter (AK40, Akrom, São Paulo, Brazil) equipped with automatic temperature compensation. The cultures were enumerated on selective agar medium as reported by Oliveira et al. [30,31] PPCP was hot bottled in polypropylene containers of $20 \mathrm{~L}$. The presence of remaining cells of L. paracasei DTA 83 and S. boulardii 17 in PPCP after the heating treatment was assessed by plate counting on MRS and WL agar medium as previously described. Plates were examined for the presence of typical colonies of each culture. 


\subsection{Determination of Kinetic Fermentation Parameters}

Initial $\left(X_{0}\right)$, maximum $\left(X_{\text {max }}\right)$ and viable cell concentration $(\log 10$ cell $/ \mathrm{mL})$ during the time $(t)(X)$, specific maximum growth rate $\left(\mu_{\max }\right)$, and Lag phase period $(\lambda)$ were normalized according to modified Gompertz's mathematical model (Equations (1) and (2)) or Baranyi's model (Equations (3) and (4)). To evaluate the adequacy of mathematical models, coefficient of determination $\left(R^{2}\right)$ obtained by DMFit software version 3.5 (Institute of Food Research, Norwich, UK), root mean square error (RMSE), bias factor ( $B f$ ), and accuracy factor $(A f)$ were determined (Equations (6)-(8) [32-34]:

$$
\begin{gathered}
y(t)=X_{\text {max }} \cdot \exp \left(-\exp \left(\left(\mu_{\text {max }} \cdot e / X_{\text {max }}\right) \cdot(\lambda-t)\right)+1\right) \\
y(t)=\ln \left(X / X_{0}\right) \\
y(t)=y_{0}+\mu_{\max } \cdot X_{\text {max }}(t)-(1 / m) \cdot \ln \left(1\left(\left(e^{\left(m \cdot \mu_{\max } \cdot X_{\max }(t)\right)}-1\right) / e^{\left(m \cdot\left(y_{\max }-y_{0}\right)\right)}\right)\right) \\
X_{\max }(t)=t+\left(1 / \mu_{\max }\right) \cdot \ln \left(e^{\left(-\mu_{\max } \cdot t\right)}+e^{\left(-h_{0}\right)}-e^{\left(\left(-\mu_{\max } \cdot t\right)-h_{0}\right)}\right) \\
h_{0}=-\ln \alpha_{0}=\ln \left(1+\left(1 / q_{0}\right)\right)=\mu_{\max } \cdot \lambda \\
R M S E=\sqrt{\sum\left(\text { value }_{\text {predicted }}-\text { value }_{\text {observed }}\right)^{2} / n} \\
A_{f}=10^{\left(\left(\sum \log \mid \text { value }_{\text {predicted }} / \text { value }_{\text {observed }} \mid\right) / n\right)} \\
B_{f}=10^{\left.\left(\left(\sum \log \text { value }_{\text {predicted }} / \text { value }_{\text {observed }}\right)\right) / n\right)}
\end{gathered}
$$

where, $X$-viable cell concentration (cell/mL) on the time $(t) ; X_{0}$-initial viable cell concentration (cell/mL); $X_{\max }$ —maximum viable cell population (ln cell $\left./ \mathrm{mL}\right) ; y(t)$ —viable cell concentration (ln cell $/ \mathrm{mL}$ ) on the time $(t) ; y_{0}$-initial viable cell concentration (ln cell $/ \mathrm{mL}$ ), $y_{\max }$ - maximum viable cell concentration $(\mathrm{ln}$ cell $/ \mathrm{mL}) ; m$-parameter related to the curving profile between the log and the stationary phase; $n$-number of experimental points taken over the experiment.

\subsection{In Vitro Trial}

Spoilage Microbial Obtention and Inoculum Preparation

Potentially food spoilage microorganisms were obtained from raw chicken sausages and semifinished chicken parts (seasoned chicken slit back and thigh) produced on industrial scale at a meat industry located in the state of Paraná, Brazil. Microorganisms were stimulated to grow in five packages per sample group incubated at $3{ }^{\circ} \mathrm{C}$ and $25{ }^{\circ} \mathrm{C}$ following the MicroLab_ShelfLife ${ }^{\circledR}$ method. A package per group was analyzed immediately after receiving the samples in the laboratory. Biological oxygen demand (BOD) incubators were used to incubate the samples with withdrawal on days 2 and $4\left(3^{\circ} \mathrm{C}\right)$ and on days 1 and $3\left(25^{\circ} \mathrm{C}\right)$. A decimal suspension $(1 / 10)$ was prepared by weighing $25 \mathrm{~g}$ of the product into $225 \mathrm{~mL}$ of PB. An aliquot $(100 \mu \mathrm{L})$ was transferred with a micropipette and sterile tip to screw-cap tubes with enrichment culture broth medium (BHI, casoy, MRS, and YPD) for growth of Gram-positive and negative bacteria and yeasts (all media were obtained from HiMedia, Mumbai, India). The tubes were incubated at $30{ }^{\circ} \mathrm{C}$ for $24 \mathrm{~h}$. Then, those with expressive microbial growth represented by an absorbance value above 0.2 at $620 \mathrm{~nm}$ (Biospectro, SP-2000UV, São Paulo, Brazil), were used to prepare the inoculum. Tubes absent of growth were incubated for more $24 \mathrm{~h}$ and re-evaluated. Remaining the absence, the tubes were eliminated from the test.

An aliquot $(1 \mathrm{~mL})$ from each tube with expressive microbial growth grouped per culture medium was transferred to an empty sterile screw-cap tube. Washed out biomass cell pellet was obtained as described in Section 2.3. The turbidity of the inoculum tube was adjusted to achieve $0.5 \mathrm{McF}$ arland standard (ca. $8.0 \mathrm{log} \mathrm{cfu} / \mathrm{mL}$ of L. paracasei DTA 83 and ca. $6.5 \log \mathrm{cfu} / \mathrm{mL}$ of $S$. boulardii 17). To perform this step accurately, a spectrophotometric device (Biospectro, SP-2000UV, São Paulo, Brazil) was used to compare the inoculum 
turbidity and the $0.5 \mathrm{McFarland}$ standard. The microbial suspension was used within $30 \mathrm{~min}$.

\subsection{Microbial Susceptibility to PPCP}

The turbidity method was performed to evaluate PPCP doses that achieved microbial control regarding spoilage microorganisms. Thus, PPCP was randomly outlined ranging concentrations from 0.5 to $3.5 \%$ in $\mathrm{BHI}$ broth medium, raising up $0.5 \%$ from tube to tube. The inoculum was prepared as described in Section 2.2. Tubes absent of PPCP and absent of inoculum were included as control and blank, respectively. The tubes were incubated at $30^{\circ} \mathrm{C}$ in a stirred thermostatically water bath and at regular $6 \mathrm{~h}$ time intervals the turbidity was measured in a spectrophotometer device (Spectrum SP-2000UV / 2000UVPC, Shanghai, China). The external surface of the tubes was dried with a paper towel and the absorbance was directly measured in the tubes, dispensing the use of cuvettes. The blank tube was used to calibrate the photometer device before measurements. Potentially dosage to achieve microbial control was expressed considering three categories: (i) totally inhibit, a category that implies the absence of growth above that dosage (absorbance value very close to the blank); (ii) partially inhibit, a category that implies a reduction in the growth with that dosage (with absorbance value lesser than the positive control); (iii) not inhibit, a category that implies a normal growth below that dosage (with absorbance value equal to the positive control).

\subsection{In Situ Trial \\ Poultry Products Processing}

Broiler chickens of about seven weeks of breeding were obtained from the meat industry suppliers located in the state of Paraná (Brazil) and used to manufacture raw chicken sausages and semifinished chicken products on a pilot industrial scale. Birds were transported to the processing plant and slaughtered according to the welfare protocol for Broilers [35]. Trained workers ensured that each bird was properly slaughtered before feather removal, evisceration, and cleaning. Carcasses were prepared for further production by removal of feathers, internal organs, and feet. Then, they were thoroughly washed and chilled to $4{ }^{\circ} \mathrm{C}$ within $4 \mathrm{~h}$ to reduce any possible foodborne pathogen growth. Carcasses were trussed after chilling in a leg dressing machine (Linco Food Systems, Trige, Denmark). Dorsal-blade part of poultry carcasses, breast, legs, and wing, which was divided into drumette, wingette (midsection) and tips, were mechanical separately in a portion cutting equipment (Linco Food Systems, Denmark) to shape desired end-products. Chicken slit back and thigh were passed by the seasoning stage with spices into a spinning drum (Incomaf, Salvador, Brazil) for $15 \mathrm{~min}$. Three batches of each part were prepared: control (no addition of PPCP), T1 (1.0\% of PPCP), and T2 (1.5\% of PPCP) (Table 1).

A stainless-steel digital thermometer was used to monitor the temperature of the batter to maintain the temperature below $7{ }^{\circ} \mathrm{C}$ throughout the process. After tumbling, the products were cold storage in a cold chamber (Gelopar, Chapada Araucária, Brazil) to achieve temperatures below $4{ }^{\circ} \mathrm{C}$. Valuable poultry meat remaining in carcasses were separated in a meat harvesting machine (607-513, Baader, Rugby, UK) and further used to prepare raw chicken sausages according to the standard formulation showed in Table 1. Chicken meat was minced in an electric grinding machine (CPG119, Cozzini, EUA) by using a stainless-steel plate disc knife with $10 \mathrm{~mm}$ hole diameter and mixed in an automatic mixer (MJ35, Jamar, Sao Paulo, Brazil) for $90 \mathrm{~s}$. Then, the other ingredients were added, and the mixture was mixed for more $90 \mathrm{~s}$. Three batches of sausage were prepared including control (no addition of PPCP), T1 (1.0\% of PPCP), and T2 (1.5\% of PPCP). After batter preparation, the meat batter was stuffed into collagen casings $(1.0 \mathrm{~m}$ of length and $26 \mathrm{~mm}$ of gauge) using an automatic stuffer (VF 610 E8, Handtmann, Biberach an der Riß, Germany) and manually twisted to shape segments of about $10 \mathrm{~cm}$ of length. 
Table 1. Chicken product formulations with addition of $1.0 \%$ (T1) or addition of $1.5 \%$ (T2) or without (Control) potentially postbiotic-containing preservative (PPCP).

\begin{tabular}{|c|c|c|c|c|c|c|}
\hline \multirow{2}{*}{ Ingredients } & \multicolumn{3}{|c|}{ Semifinished Chicken Products } & \multicolumn{3}{|c|}{ Raw Chicken Sausages } \\
\hline & Control & T1 & T2 & Control & T1 & T2 \\
\hline Chicken parts (slit back or thigh) & $92-93$ & $91-92$ & $90.5-91.5$ & & & \\
\hline Minced chicken meat & & & & 86.34 & 85.34 & 84.84 \\
\hline Water & $2-5$ & $2-5$ & $2-5$ & 8 & 8 & 8 \\
\hline Seasoning ${ }^{1}$ & 2.1 & 2.1 & 2.1 & 2.87 & 2.87 & 2.87 \\
\hline Sodium phosphate & 0.5 & 0.5 & 0.5 & 0.25 & 0.25 & 0.25 \\
\hline Sodium trypoliphosphate & & & & 2.5 & 2.5 & 2.5 \\
\hline Sodium erythorbate & 0.6 & 0.6 & 0.6 & & & \\
\hline Annatto dye & 0.02 & 0.02 & 0.02 & & & \\
\hline Sodium lactate & $0-2$ & $0-2$ & $0-2$ & & & \\
\hline Curing Salt ${ }^{2}$ & & & & 0.12 & 0.12 & 0.12 \\
\hline Cochineal carmine dye & & & & 0.02 & 0.02 & 0.02 \\
\hline PPCP & & 1.0 & 1.5 & & 1.0 & 1.5 \\
\hline
\end{tabular}

${ }^{1}$ Sodium chloride, pepper, sucrose, and monosodium glutamate. ${ }^{2}$ Traditional cure with direct addition of curing salt to obtain a final concentration at $150 \mathrm{ppm}$ of sodium nitrite.

Five packages of each sample group were packaged in polyethylene bags and sealed in a heat sealer. Freezing tunnels (Recrusul, Sapucaia do Sul, Brazil) were used to freeze the products at $-12{ }^{\circ} \mathrm{C}$. The sample groups were blind coded and shipped to the laboratory in isothermal boxes with ice bricks. Codes were unblinded only after performing the durability study.

\subsection{Durability Study}

A predictive microbial method, named MicroLab_ShelfLife ${ }^{\circledR}$, was used to perform a durability study in raw chicken sausages and semifinished chicken products. It was carried out considering a realistic temperature profile in three $\mathrm{R}$, including DC and M.

One package per group was analyzed soon after being received in the laboratory to count of the initial microbial load (time zero). Microbial growth was stimulated to grow by pair incubation at low $\left(3{ }^{\circ} \mathrm{C}\right)$ and high $\left(25^{\circ} \mathrm{C}\right)$ temperatures. BOD incubators were used for precise temperature control. The doors were kept closed, except during sample withdrawals. The method ISO 4833 (2013), with few modifications as reported by Oliveira et al. [30], was used for enumeration of microorganisms in samples, with counts at intervals on days 2 and 4 (low temperature) and on days 1 and 3 (high temperature) of incubation [36]. The MicroLab_ShelfLife ${ }^{\circledR}$ was compiled to calculate results by using at least two successive dilution levels (Equation (9)) and to obtain information about the method parameters and the microbial growth curve at a chosen dynamic temperature profile.

$$
N=\frac{\sum C}{V[n 1+0.1 n 2) d}
$$

where, $\sum c$ - sum of the colonies counted on the two plates retained from two successive dilutions (at least one of which contains a minimum of 10 colonies); $V$-volume of inoculum placed in each well (mL); $n 1$ and $n 2$-number of wells selected in the first dilution and number of wells selected in the second dilution, respectively; and $d$-level of the first dilution retained.

The microbiological limit that separates good quality from marginally acceptable quality $(m=5 \log \mathrm{cfu} / \mathrm{g})$ prescribed by the regulatory agencies [8-10] was inserted in the predictive modeling package as borderline to indicate the use-by date of the products.

\subsection{Temperature Profile of the Test}

An electronic device (QII343, XpressPDF Logger, Emerson, USA) with a temperature range from $-40{ }^{\circ} \mathrm{C}$ to $85^{\circ} \mathrm{C}\left( \pm 0.5^{\circ} \mathrm{C}\right.$ accuracy $)$ was used to elucidate the temperatures to 
which the products were exposed during transport and sale. The equipment was adjusted as follows: sensor reaction time of $5 \mathrm{~min}$, a sampling frequency of $1 \mathrm{~h}$ to 10 days, the data storage capacity of 8000 readings. At the end of the acquisition period, the logger was recovered, and data were downloaded into a computer. Data were grouped for hourly mean over one day to fit the data in the MicroLab_ShelfLife ${ }^{\circledR}$. Three routes (R1, R2, and R3) were strategically included in the study, encompassing three DC and three M. DC1, which is located in the city of Penha, state of Paraná (Brazil), is a common and mandatory route to other routes. In R1, from DC1 the product is shipped to DC2, located in the city of Bebedouro, state of São Paulo (Brazil), after to DC3 (Bebedouro, São Paulo, Brazil) and finally to the M1 (Bebedouro, São Paulo, Brazil). In R2, from DC1 the product is shipped to M2, located in the city of Cafelândia, state of Paraná (Brazil). In R3, from DC1 the product is shipped to DC2 and to the M3 (Bebedouro, São Paulo, Brazil), as depicted in Figures 1 and 2 .

\subsection{Statistical Analysis}

Results were presented as Mean \pm Standard Error (SE) from replicates. The assumption of normal data distribution was assessed with the Shapiro-Wilk test. Grubbs and Tietjen-Moore tests were used for detecting a single or more than one outlier. Data were evaluated by analysis of variance (ANOVA), followed by Fisher's LSD test $(p<0.05)$ using the software Addinsoft (2019)—XLSTAT, Boston, MA, USA.

Confidence interval for the mean and prediction interval for the sample of linear regression were estimated according to Equations (10), (11) and (12), respectively:

$$
\begin{gathered}
(\dot{\mathrm{Y}} \pm \mathrm{t} \alpha / 2 * \mathrm{SE} * \sqrt{h i}) \\
(\dot{\mathrm{Y}} \pm \mathrm{t} \alpha / 2 * \mathrm{SE} * \sqrt{1+h i}) \\
\left(h i=1 / n+(x i-x)^{2} / \sum(x i-x)^{2}\right)
\end{gathered}
$$

where $\mathrm{Y}$-value of estimative; $t \alpha / 2$-value of Student's $t$ distribution; $n$-number of observations; $x i$-value of sample, $x$-mean.

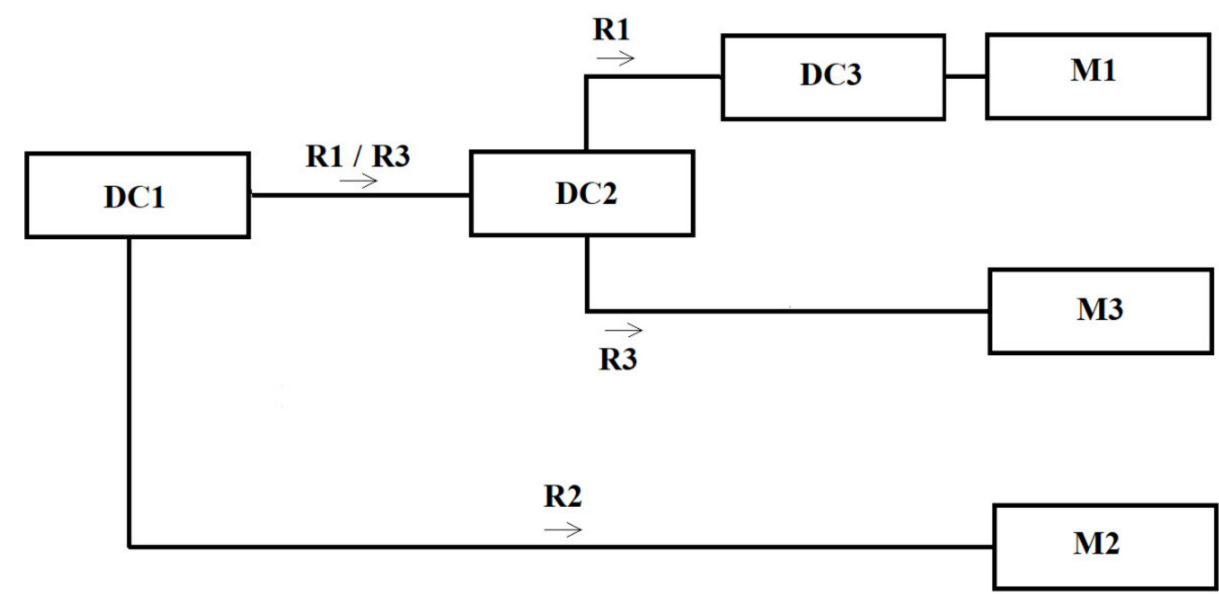

Figure 1. Logistic distribution routes. Route (R1)—from distribution center DC1 (Penha, Paraná, Brazil) to distribution center DC2 (Bebedouro, São Paulo, Brazil), to distribution center DC3 (Bebedouro, São Paulo, Brazil), and to market M1 (Bebedouro, São Paulo, Brazil). Route (R2)from distribution center DC1 (Penha, Paraná, Brazil) to market M2 (Cafelândia, Paraná, Brazil). Route (R3)—from distribution center DC1 (Penha, Paraná, Brazil) to distribution center DC2 (Bebedouro, São Paulo, Brazil), and to market M3 (Bebedouro, São Paulo, Brazil). Retention time at DC was included in modeling (2 days) according to information from meat industry. 


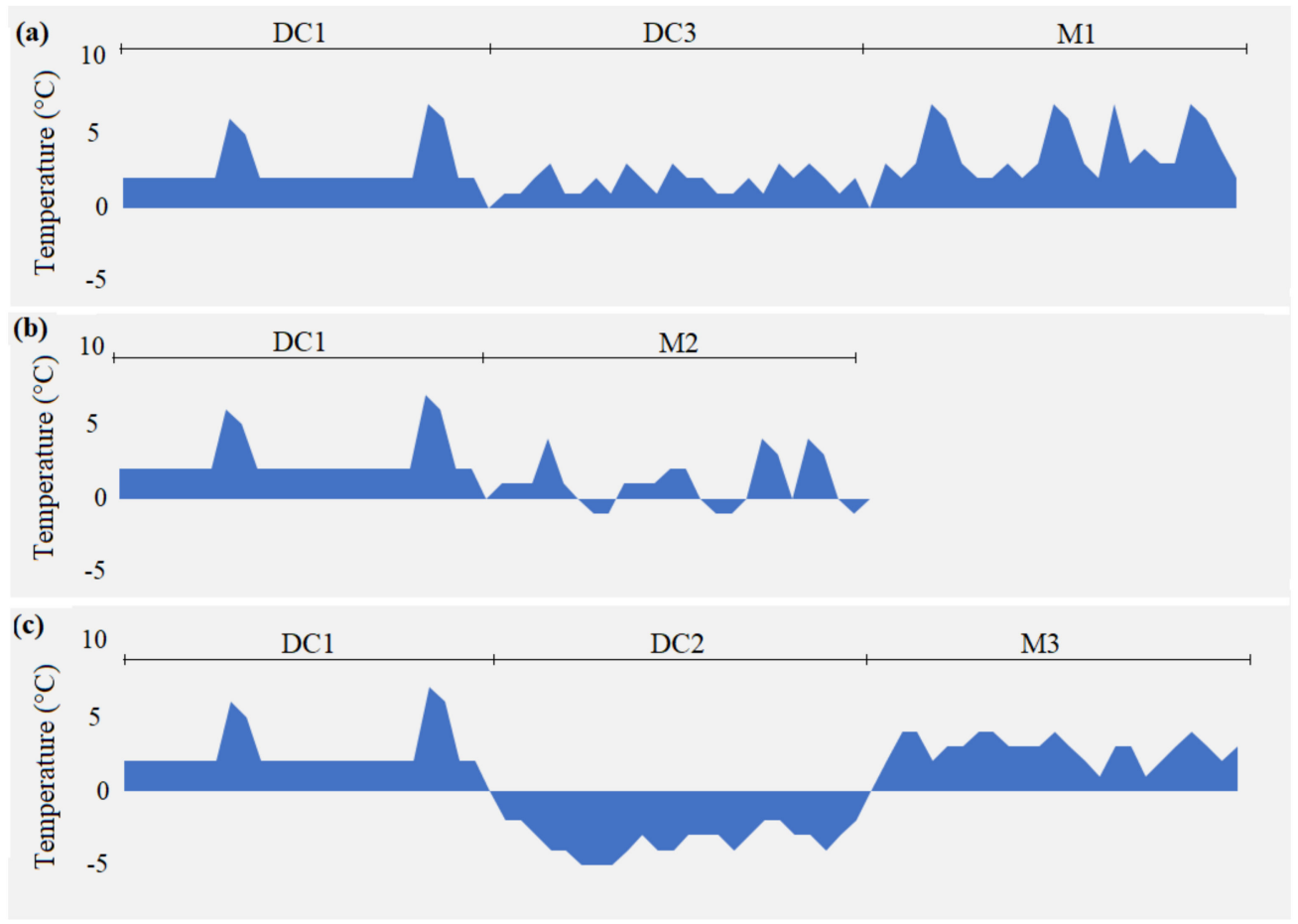

Figure 2. Temperature profile based on hourly variation during a 1-day period to represent distribution centers (DC1, DC2, and DC3) and markets (M1, M2, and M3) in logistic distribution routes R1 (a), R2 (b), and R3 (c). DC2 was eliminated from R1 due to insignificance of microbial growth once products were stored at a temperature profile constantly below zero, keeping frozen storage temperatures.

A computational predictive modeling package named MicroLab_Shelf-Life ${ }^{\circledR}$ was used to predict the use-by date of vacuum-packaged cooked sausages (Appendix A). The parameters of the model (Ngrowth and Ndeceleration) were used to represent daily microbial population growth $(\log \mathrm{cfu} / \mathrm{g})$ in the microbial growth $(\log )$ and deceleration phases. The upper limit for total microbial count of $5 \log \mathrm{cfu} / \mathrm{g}$ was considered as the method borderline in the durability study.

\section{Results}

L. paracasei DTA 83 converted glucose into acids and produced PPCP. In addition, L. paracasei DTA 83 and S. boulardii 17 showed an amensal interaction, without severe prejudice to any strain (Table S2 and Figure 3).

PPCP may be more effective as a preservative than organic acids since semicultured is an adequate fermentation system for the production of lactic and acetic acids by L. paracasei DTA 83 and S. boulardii 17, respectively. Moreover, other preservatives, such as biocides, may be produced by these strains during fermentation. When the concentrations of produced lactic acid and acetic acid or biocides were not measured in the present study, the stressful effects on chicken-related contaminants were designed and demonstrated in Figure S1.

The in vitro trial showed that microbial susceptibility of chicken-related contaminants was directly proportional to the added concentration of PPCP. When a concentration of PPCP below $0.5 \%$ was added to raw chicken sausages or semifinished chicken products, the susceptibility of chicken-related contaminants was not inhibited. Partial inhibition was obtained by adding 1.0 to $2.5 \%$ of PPCP and total inhibition was determined by adding above $3.0 \%(p>0.95)$. 


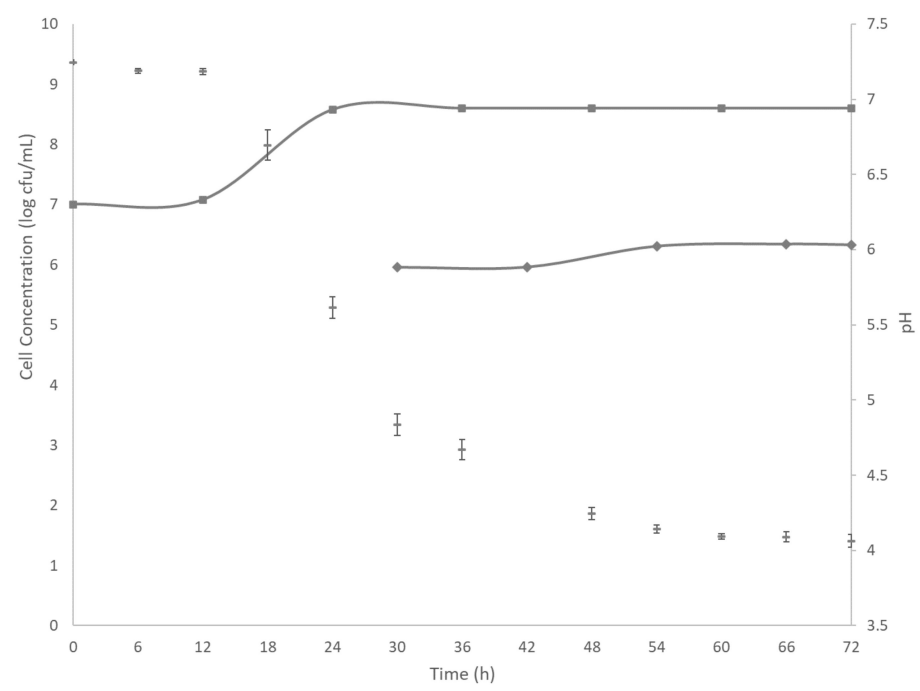

Figure 3. Viability of L. paracasei DTA $83(-)$ ) and S. boulardii $17(\longrightarrow)$ ) and $\mathrm{pH}$ measurement (unconnected points) during potentially postbiotic-containing preservative (PPCP) production. ( I ) Standard Error.

Concentrations of 1.0 and $1.5 \%$ of PPCP were chosen to be studied in raw chicken sausages and semifinished chicken products to obtain in situ partial inhibitory effects on spoilage microorganisms to extend the use-by date. Although concentrations of PPCP above $3.0 \%$ showed a remarkable inhibitory potential, its addition can severely impact the formulation cost.

Linear regression parameters of the microbial growth of chicken-related contaminants at different concentrations of PPCP are shown in Figure 4 and Table S1.
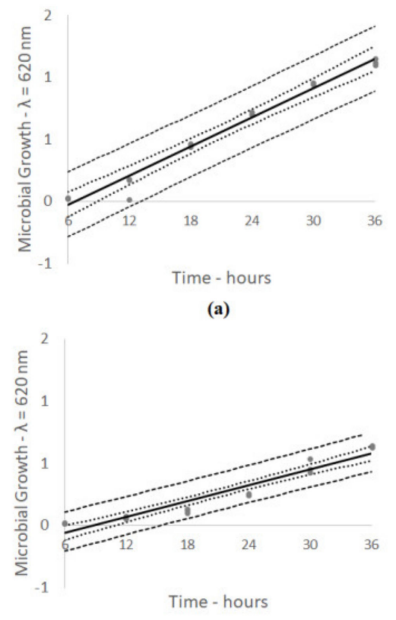

(e)

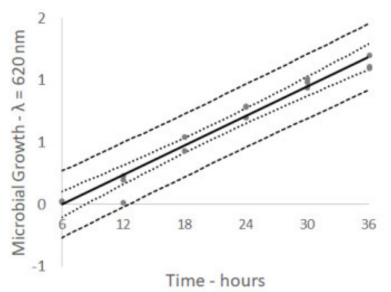

(b)

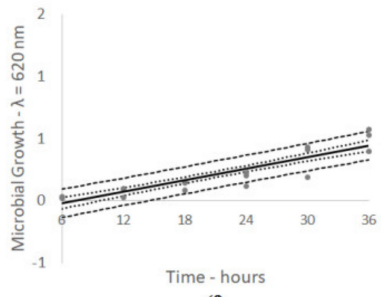

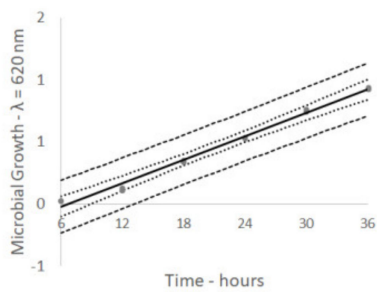

(c)

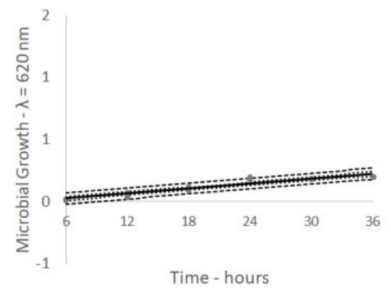

(g)

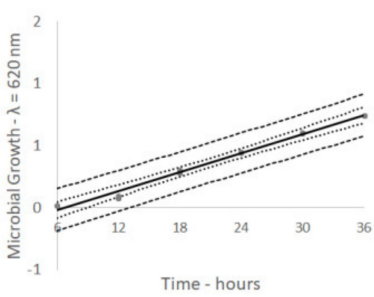

(d)

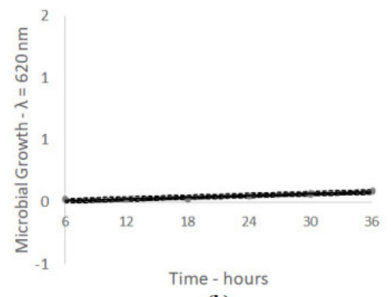

(h)

Figure 4. Linear regression $(-)$ parameters of microbial growth of chicken-related contaminants at different concentrations of potentially postbiotic-containing preservative (PPCP). Confidence interval for mean (....) and prediction interval for sample (---) of period with microbial growth (from 6 to $36 \mathrm{~h}$ of incubation at $36{ }^{\circ} \mathrm{C}$ ) at different concentrations of potentially postbiotic-containing preservative (PPCP): (a) $0.0 \%$; (b) $0.5 \%$; (c) $1.0 \%$; (d) $1.5 \%$; (e) $2.0 \%$; (f) $2.5 \%$; (g) $3.0 \%$; (h) $3.5 \%$. Confidence interval for mean and prediction interval for sample of linear regression were estimated according to Equation (10) $(\dot{\mathrm{Y}} \pm t \alpha / 2 * S E * \sqrt{h i}$, Equation (11) $(\dot{\mathrm{Y}} \pm t \alpha / 2 * S E * \sqrt{1+h i})$, and Equation (12) $\left(h i=1 / n+(x i-x)^{2} / \sum(x i-x)^{2}\right)$, where $\dot{Y}$-value of estimative; $t \alpha / 2$-value of Student's $\mathrm{t}$ distribution; $n$-number of observations; $x i$-value of sample, $x$-mean. 
All three R included in the study began in DC1, located in Bebedouro, Paraná, Brazil. As expected, Ngrowth and Ndeceleration parameters of the model were equal in the same sample group (control or T1 or T2) in R1, R2, and R3. However, significant differences were observed when different sample groups were compared (control $>\mathrm{T} 1>\mathrm{T} 2$ ), which indicates the potential effects of PPCP to control spoilage growth in raw chicken sausages and semifinished chicken products. These results were in line with those observed during the 2nd and 3rd periods (Tables 2-4).

Table 2. Durability study of raw chicken sausages (control, 1.0\% (T1), and 1.5\% (T2)) of added potentially postbiotic-containing preservative (PPCP) under a dynamic temperature profile in distribution routes $(\mathrm{R})$.

\begin{tabular}{|c|c|c|c|c|c|c|c|c|c|c|c|}
\hline & \multicolumn{2}{|c|}{ Sample Incubation } & \multicolumn{9}{|c|}{ Treatments } \\
\hline & $\begin{array}{c}\text { Temperature } \\
\left({ }^{\circ} \mathrm{C}\right)\end{array}$ & $\begin{array}{l}\text { Time } \\
\text { (Days) }\end{array}$ & & Control & & & T1 & & & $\mathrm{T} 2$ & \\
\hline \multirow{5}{*}{$\begin{array}{l}\text { Laboratorial data } \\
\quad(\log \mathrm{cfu} / \mathrm{g})\end{array}$} & & 0 & & 3.80 & & & 3.75 & & & 3.72 & \\
\hline & \multirow{2}{*}{3} & 2 & \multirow{2}{*}{\multicolumn{3}{|c|}{$\begin{array}{l}3.83 \\
3.84\end{array}$}} & \multicolumn{3}{|c|}{3.77} & \multicolumn{3}{|c|}{3.72} \\
\hline & & 4 & & & & \multicolumn{3}{|c|}{3.76} & \multicolumn{3}{|c|}{3.74} \\
\hline & \multirow{2}{*}{25} & 1 & \multirow{2}{*}{\multicolumn{3}{|c|}{$\begin{array}{l}5.53 \\
9.30 \\
\end{array}$}} & \multirow{2}{*}{\multicolumn{3}{|c|}{$\begin{array}{l}5.38 \\
6.32\end{array}$}} & \multirow{2}{*}{\multicolumn{3}{|c|}{$\begin{array}{l}5.37 \\
6.11 \\
\end{array}$}} \\
\hline & & 3 & & & & & & & & & \\
\hline \multirow{5}{*}{$\begin{array}{l}\text { Specific maximum } \\
\text { growth rate } \\
(\log \mathrm{cfu} / \mathrm{g} / \mathrm{day})\end{array}$} & \multirow{2}{*}{3} & L phase & \multirow{2}{*}{\multicolumn{3}{|c|}{$\begin{array}{l}0.0125 \\
0.0110\end{array}$}} & \multirow{2}{*}{\multicolumn{3}{|c|}{$\begin{array}{l}0.0062 \\
0.0055\end{array}$}} & \multirow{2}{*}{\multicolumn{3}{|c|}{$\begin{array}{l}0.0025 \\
0.0022\end{array}$}} \\
\hline & & D phase & & & & & & & & & \\
\hline & \multirow{2}{*}{25} & L phase & \multirow{2}{*}{\multicolumn{3}{|c|}{$\begin{array}{l}1.7817 \\
1.5742\end{array}$}} & \multirow{2}{*}{\multicolumn{3}{|c|}{$\begin{array}{l}1.2433 \\
1.0986\end{array}$}} & \multirow{2}{*}{\multicolumn{3}{|c|}{$\begin{array}{l}1.2233 \\
1.0809\end{array}$}} \\
\hline & & D phase & & & & & & & & & \\
\hline & & & R1 & $\mathrm{R} 2$ & $\mathrm{R} 3$ & R1 & $\mathrm{R} 2$ & $\mathrm{R} 3$ & $\mathrm{R} 1$ & $\mathrm{R} 2$ & $\mathrm{R} 3$ \\
\hline \multirow{3}{*}{ 1st period } & \multirow{2}{*}{\multicolumn{2}{|c|}{$\begin{array}{c}\text { Ngrowth (log cfu/g/day) }^{1} \\
\text { Ndeceleration (log } \\
\text { cfu/g/day) }\end{array}$}} & 0.0423 & 0.0423 & 0.0423 & 0.0292 & 0.0292 & 0.0292 & 0.0282 & 0.0282 & 0.0282 \\
\hline & & & 0.0374 & 0.0374 & 0.0374 & 0.0258 & 0.0258 & 0.0258 & 0.0249 & 0.0249 & 0.0249 \\
\hline & $\mathrm{Ft}(\mathrm{n})^{3}$ & & 1.1318 & 1.1318 & 1.1318 & 1.1318 & 1.1318 & 1.1318 & 1.1318 & 1.1318 & 1.1318 \\
\hline \multirow{3}{*}{ 2nd period } & \multirow{2}{*}{\multicolumn{2}{|c|}{$\begin{array}{c}\text { Ngrowth (log cfu/g/day) }{ }^{1} \\
\text { Ndeceleration (log } \\
\text { cfu/g/day) }\end{array}$}} & 0.0026 & 0.0127 & & 0.0013 & 0.0083 & & 0.0005 & 0.0075 & \\
\hline & & & 0.0025 & 0.0126 & & 0.0012 & 0.0083 & & 0.0005 & 0.0074 & \\
\hline & $\mathrm{Ft}(\mathrm{n})^{3}$ & & 1.0548 & 1.0034 & & 1.0548 & 1.0034 & & 1.0548 & 1.0034 & \\
\hline \multirow{3}{*}{ 3rd period } & \multirow{3}{*}{\multicolumn{2}{|c|}{$\begin{array}{c}\text { Ngrowth (log cfu/g/day) }^{1} \\
\text { Ndeceleration (log } \\
\text { cfu/g/day) } \\
\operatorname{Ft}(\mathrm{n})^{3}\end{array}$}} & 0.0998 & 0.0127 & 0.0290 & 0.0679 & 0.0083 & 0.0185 & 0.0643 & 0.0075 & 0.0156 \\
\hline & & & 0.0806 & 0.0141 & 0.0252 & 0.0549 & 0.0093 & 0.0161 & 0.0519 & 0.0083 & 0.0136 \\
\hline & & & 1.2381 & 0.8971 & 1.1501 & 1.2381 & 0.8971 & 1.1501 & 1.2381 & 0.8971 & 1.1501 \\
\hline Use-by date-days & & & 16 & 91 & 43 & 22 & 146 & 69 & 24 & 167 & 83 \\
\hline & & $\begin{array}{l}\text { owth-dai } \\
\text { bial growtl } \\
\text { ) in microbi } \\
\text { ation varia } \\
\text { nic temper }\end{array}$ & $\begin{array}{l}\text { microbia } \\
\text { redictor } \\
\text { decelerat } \\
\text { factor } t \\
\text { are profil }\end{array}$ & $\begin{array}{l}\text { populati } \\
\text { MicroLal } \\
\text { on phase } \\
\text { t describ } \\
\text { based on }\end{array}$ & $\begin{array}{l}\text { ghelfLif } \\
\text { terminec } \\
\text { specific } \\
\text { ourly va }\end{array}$ & $\begin{array}{l}(\log \mathrm{cfu} / \\
){ }^{2} \mathrm{Nde} \\
\text { rowicrob } \\
\text { rowth ra } \\
\text { ation acc }\end{array}$ & $\begin{array}{l}\text { in mic } \\
\text { leration } \\
\text { l growtl } \\
\mathrm{s} \text { betwe } \\
\text { ding to }\end{array}$ & $\begin{array}{l}\text { bial gro } \\
\text { daily m } \\
\text { redictor } \\
\text { log and } \\
\text { easurem }\end{array}$ & $\begin{array}{l}\text { th }(\log ) \\
\text { cobial po } \\
\text { MicroLab } \\
\text { ecelerati } \\
\text { ts in loce }\end{array}$ & $\begin{array}{l}\text { ase dete } \\
\text { dlation g } \\
\text { helfLife } \\
\text { phases } \\
\text { Figure 2) }\end{array}$ & $\begin{array}{l}\text { mined by } \\
{ }^{3} \mathrm{FT}(\mathrm{n})- \\
\text { a chosen }\end{array}$ \\
\hline & $\mathrm{b}$ & $\begin{array}{l}3 . \text { Durab } \\
\text { tially pos } \\
\text { n routes }\end{array}$ & $\begin{array}{l}\text { ty study } \\
\text { lotic-cor }\end{array}$ & $\begin{array}{l}\text { of seaso } \\
\text { aining } \mathrm{p}\end{array}$ & d chick & (PPCP) & (contr & ynamic & 1), and & ce profil & $\begin{array}{l}\text { f added } \\
\text { in distri- }\end{array}$ \\
\hline & Sample I & pation & & & & & reatmen & & & & \\
\hline & $\begin{array}{c}\text { Temperature } \\
\left({ }^{\circ} \mathrm{C}\right)\end{array}$ & $\begin{array}{l}\text { Time } \\
\text { (Days) }\end{array}$ & & Control & & & T1 & & & $\mathbf{T} 2$ & \\
\hline & & 0 & & 3.90 & & & 3.92 & & & 4.01 & \\
\hline & 3 & 2 & & 4.08 & & & 4.07 & & & 4.01 & \\
\hline$(\log \mathrm{cfu} / \mathrm{g})$ & 3 & 4 & & 4.03 & & & 4.01 & & & 4.05 & \\
\hline & & 1 & & 7.11 & & & 5.32 & & & 5.25 & \\
\hline & 25 & 3 & & 9.40 & & & 6.91 & & & 7.34 & \\
\hline
\end{tabular}


Table 3. Cont.

\begin{tabular}{|c|c|c|c|c|c|c|c|c|c|c|c|}
\hline & \multicolumn{2}{|c|}{ Sample Incubation } & \multicolumn{9}{|c|}{ Treatments } \\
\hline & $\begin{array}{c}\text { Temperature } \\
\left({ }^{\circ} \mathrm{C}\right)\end{array}$ & $\begin{array}{l}\text { Time } \\
\text { (Days) }\end{array}$ & \multicolumn{3}{|c|}{ Control } & \multicolumn{3}{|c|}{ T1 } & \multicolumn{3}{|c|}{ T2 } \\
\hline \multirow{4}{*}{$\begin{array}{l}\text { Specific maximum } \\
\text { growth rate } \\
(\log \mathrm{cfu} / \mathrm{g} / \text { day })\end{array}$} & \multirow[b]{2}{*}{3} & L phase & \multirow{2}{*}{\multicolumn{3}{|c|}{$\begin{array}{l}0.0613 \\
0.0541\end{array}$}} & \multirow{2}{*}{\multicolumn{3}{|c|}{$\begin{array}{l}0.0488 \\
0.0431\end{array}$}} & \multirow{2}{*}{\multicolumn{3}{|c|}{$\begin{array}{l}0.0050 \\
0.0044\end{array}$}} \\
\hline & & D phase & & & & & & & & & \\
\hline & \multirow{2}{*}{25} & L phase & \multirow{2}{*}{\multicolumn{3}{|c|}{$\begin{array}{l}2.5217 \\
2.2281\end{array}$}} & \multirow{2}{*}{\multicolumn{3}{|c|}{$\begin{array}{l}1.1983 \\
1.0588\end{array}$}} & \multirow{2}{*}{\multicolumn{3}{|c|}{$\begin{array}{l}1.1750 \\
1.0382\end{array}$}} \\
\hline & & D phase & & & & & & & & & \\
\hline & & & R1 & $\mathrm{R} 2$ & R3 & R1 & $\mathrm{R} 2$ & $\mathrm{R} 3$ & R1 & R2 & R3 \\
\hline \multirow{3}{*}{ 1st period } & \multirow{3}{*}{\multicolumn{2}{|c|}{$\begin{array}{c}\text { Ngrowth (log cfu/g/day) }{ }^{1} \\
\text { Ndeceleration (log } \\
\text { cfu/g/day) }{ }^{2} \\
\end{array}$}} & 0.0661 & 0.0661 & 0.0661 & 0.0343 & 0.0343 & 0.0343 & 0.0274 & 0.0274 & 0.0274 \\
\hline & & & 0.0584 & 0.0584 & 0.0584 & 0.0303 & 0.0303 & 0.0303 & 0.0242 & 0.0242 & 0.0242 \\
\hline & & & 1.1318 & 1.1318 & 1.1318 & 1.1318 & 1.1318 & 1.1318 & 1.1318 & 1.1318 & 1.1318 \\
\hline \multirow{3}{*}{ 2nd period } & \multirow{3}{*}{\multicolumn{2}{|c|}{$\begin{array}{c}\text { Ngrowth (log cfu/g/day) }{ }^{1} \\
\text { Ndeceleration (log } \\
\text { cfu/g/day) }{ }^{2} \\
\mathrm{Ft}(\mathrm{n})^{3}\end{array}$}} & 0.0128 & 0.0267 & & 0.0102 & 0.0167 & & 0.0010 & 0.0077 & \\
\hline & & & 0.0121 & 0.0266 & & 0.0096 & 0.0166 & & 0.0010 & 0.0077 & \\
\hline & & & 1.0548 & 1.0034 & & 1.0548 & 1.0034 & & 1.0548 & 1.0034 & \\
\hline \multirow{3}{*}{ 3rd period } & \multirow{3}{*}{\multicolumn{2}{|c|}{$\begin{array}{c}\text { Ngrowth (log cfu/g/day) }{ }^{1} \\
\text { Ndeceleration (log } \\
\text { cfu/g/day) })^{2} \\
\text { Ft(n) }{ }^{3}\end{array}$}} & 0.1718 & 0.0267 & 0.0713 & 0.0953 & 0.0167 & 0.0476 & 0.0636 & 0.0077 & 0.0168 \\
\hline & & & 0.1387 & 0.0298 & 0.0620 & 0.0770 & 0.0186 & 0.0414 & 0.0514 & 0.0086 & 0.0146 \\
\hline & & & 1.2381 & 0.8971 & 1.1501 & 1.2381 & 0.8971 & 1.1501 & 1.2381 & 0.8971 & 1.1501 \\
\hline \multirow[t]{5}{*}{ Use-by date-days } & & & 10 & 39 & 18 & 15 & 63 & 26 & 19 & 124 & 60 \\
\hline & \multirow{2}{*}{\multicolumn{11}{|c|}{$\begin{array}{l}{ }^{1} \text { Ngrowth-daily microbial population growth }(\log \mathrm{cfu} / \mathrm{g}) \text { in microbial growth }(\mathrm{log}) \text { phase determined by } \\
\left.\text { microbial growth predictor (MicroLab_ShelfLife }{ }^{\circledR}\right) ;{ }^{2} \text { Ndeceleration-daily microbial population growth (log } \\
\left.\text { cfu/g) in microbial deceleration phase determined by microbial growth predictor (MicroLab_ShelfLife }{ }^{\circledR}\right) ;{ }^{3} \mathrm{FT}(\mathrm{n})- \\
\text { correlation variable factor that describes specific growth rates between log and deceleration phases at a chosen } \\
\text { dynamic temperature profile based on hourly variation according to measurements in loco (Figure } 2) \text {. } \\
\text { Table } 4 \text {. Durability study of seasoned chicken thigh (control, } 1.0 \% \text { (T1), and } 1.5 \% \text { (T2)) of added poten- } \\
\text { tially postbiotic-containing preservative (PPCP) under a dynamic temperature profile in distribution } \\
\text { routes (R). }\end{array}$}} \\
\hline & & & & & & & & & & & \\
\hline & \multicolumn{2}{|c|}{ Sample Incubation } & \multicolumn{9}{|c|}{ Treatments } \\
\hline & $\begin{array}{c}\text { Temperature } \\
\left({ }^{\circ} \mathrm{C}\right)\end{array}$ & $\begin{array}{l}\text { Time } \\
\text { (Days) }\end{array}$ & & Control & & & T1 & & & $\mathrm{T} 2$ & \\
\hline \multirow{5}{*}{$\begin{array}{l}\text { Laboratorial data } \\
\quad(\log \mathrm{cfu} / \mathrm{g})\end{array}$} & & 0 & & 3.91 & & & 3.82 & & & 3.79 & \\
\hline & 3 & 2 & & 4.00 & & & 3.83 & & & 3.84 & \\
\hline & 3 & 4 & & 4.03 & & & 3.92 & & & 3.93 & \\
\hline & 25 & 1 & & 6.78 & & & 6.29 & & & 4.41 & \\
\hline & 20 & 3 & & 9.40 & & & 8.01 & & & 5.83 & \\
\hline & 3 & L phase & & 0.0375 & & & 0.0150 & & & 0.0300 & \\
\hline Specific maximum & 3 & D phase & & 0.0331 & & & 0.0133 & & & 0.0265 & \\
\hline (log cfu/g/day) & 25 & L phase & & 2.3500 & & & 1.9333 & & & 0.6500 & \\
\hline & 25 & D phase & & 2.0764 & & & 1.7082 & & & 0.5743 & \\
\hline & & & R1 & $\mathrm{R} 2$ & $\mathrm{R} 3$ & R1 & $\mathrm{R} 2$ & $\mathrm{R} 3$ & R1 & R2 & R3 \\
\hline & Ngrowth (log & $/$ g/day) ${ }^{1}$ & 0.0588 & 0.0588 & 0.0588 & 0.0461 & 0.0461 & 0.0461 & 0.0191 & 0.0191 & 0.0191 \\
\hline 1st period & $\begin{array}{r}\text { Ndeceler } \\
\mathrm{cfu} / \mathrm{g}\end{array}$ & ${ }^{2}(\log$ & 0.0520 & 0.0520 & 0.0520 & 0.0407 & 0.0407 & 0.0407 & 0.0169 & 0.0169 & 0.0169 \\
\hline & $\mathrm{Ft}(\mathrm{n})^{3}$ & & 1.1318 & 1.1318 & 1.1318 & 1.1318 & 1.1318 & 1.1318 & 1.1318 & 1.1318 & 1.1318 \\
\hline & Ngrowth (log & $/$ g/day) ${ }^{1}$ & 0.0062 & 0.0210 & & 0.0140 & 0.0140 & & 0.0078 & 0.0098 & \\
\hline 2nd period & $\begin{array}{c}\text { Ndeceler } \\
\text { cfu/g }\end{array}$ & $n^{2}(\log$ & 0.0059 & 0.0209 & & 0.0140 & 0.0140 & & 0.0074 & 0.0097 & \\
\hline & $\mathrm{Ft}(\mathrm{n})^{3}$ & & 1.0548 & 1.0034 & & 1.0548 & 1.0034 & & 1.0548 & 1.0034 & \\
\hline
\end{tabular}


Table 4. Cont.

\begin{tabular}{|c|c|c|c|c|c|c|c|c|c|c|c|}
\hline & \multicolumn{2}{|c|}{ Sample Incubation } & \multicolumn{9}{|c|}{ Treatments } \\
\hline & $\begin{array}{c}\text { Temperature } \\
\left({ }^{\circ} \mathrm{C}\right)\end{array}$ & $\begin{array}{l}\text { Time } \\
\text { (Days) }\end{array}$ & & Control & & & $\mathbf{T 1}$ & & & $\mathrm{T} 2$ & \\
\hline \multirow{3}{*}{ 3rd period } & \multirow{3}{*}{\multicolumn{2}{|c|}{$\begin{array}{c}\text { Ngrowth (log cfu/g/day) }{ }^{1} \\
\text { Ndeceleration (log } \\
\text { cfu/g/day) }{ }^{2} \\
\text { Ft(n) }{ }^{3}\end{array}$}} & 0.1464 & 0.0210 & 0.0528 & 0.1093 & 0.0140 & 0.0324 & 0.0542 & 0.0098 & 0.0283 \\
\hline & & & 0.1182 & 0.0234 & 0.0459 & 0.0883 & 0.0156 & 0.0282 & 0.0438 & 0.0109 & 0.0246 \\
\hline & & & 1.2381 & 0.8971 & 1.1501 & 1.2381 & 0.8971 & 1.1501 & 1.2381 & 0.8971 & 1.1501 \\
\hline Use-by date-days & & & 11 & 49 & 23 & 14 & 80 & 38 & 26 & 122 & 46 \\
\hline
\end{tabular}

${ }^{1}$ Ngrowth - daily microbial population growth (log cfu/g) in microbial growth (log) phase determined by microbial growth predictor (MicroLab_ShelfLife $\left.{ }^{\circledR}\right) ;{ }^{2}$ Ndeceleration-daily microbial population growth (log $\mathrm{cfu} / \mathrm{g}$ ) in microbial deceleration phase determined by microbial growth predictor (MicroLab_ShelfLife $\left.{ }^{\circledR}\right) ;{ }^{3}$ FT(n)correlation variable factor that describes specific growth rates between log and deceleration phases at a chosen dynamic temperature profile based on hourly variation according to measurements in loco (Figure 2).

\section{Discussion}

Gompertz's modified and Baranyi models indicated greater growth of L. paracasei DTA 83 (ca. $1.6 \log \mathrm{cfu} / \mathrm{g}$ ) than S. boulardii 17 (ca. $0.65 \mathrm{log} \mathrm{cfu} / \mathrm{g}$ ) during fermentation for PPCP production (Table S2 and Figure 3). Latency in Lag phase ( $\lambda$ ) was longer for S. boulardii 17 showing that the metabolites produced by L. paracasei DTA 83 , especially lactic acid, may be stress factors for the growth of $S$. boulardii 17. Although this point seems to be negative, it was strategically designed once $S$. boulardii 17 can produce acetic acid in stressful conditions as reported by Paula and colleagues [33].

S. boulardii 17 performance to assimilate sugars in acid conditions was previously demonstrated by Silva and colleagues, revealing its suitability to be associated with acid lactic bacteria in a culture system [28]. Moradi and colleagues reported that $S$. boulardii is more tolerant to acidic $\mathrm{pH}$ and temperature variation than other $S$. cerevisiae strains and can survive at $\mathrm{pH}$ values as low as 2.0 [37]. Otherwise, L. paracasei DTA 81, which is a close genetic strain to the L. paracasei DTA 83 used in the present study [24], showed sensitivity to the metabolites produced by $S$. boulardii, suggesting that the semiseparated coculture system is an adequate choice to culture the strains in fermentation processes [28].

Stanojević-Nikolić and colleagues related the antimicrobial activity of lactic acid against pathogen and spoilage microorganisms. Lactic acid minimal inhibitory concentration for bacteria was about ten times lesser than to inhibit yeasts. Most of the microorganisms studied by the authors are chicken-related contaminants, indicating that acid lactic can be a potential preservative for chicken products to prevent food-born pathogenic and spoilage microorganisms. The inhibitory effect against spoilage microbial growth may be optimized using PPCP when bacteriocins are produced during lactic acid fermentation [38].

In addition, acetic acid has presented good antimicrobial activity against various microorganisms such as bacteria, yeasts, and molds. Halstead and colleagues demonstrated the effect of acetic acid against Pseudomonas aeruginosa, Acinetobacter baumannii, Escherichia coli, Staphylococcus aureus, and Klebsiella pneumoniae. Minimum inhibitory concentrations from 0.16 to $0.31 \%$ were found to prevent biofilms formation for all isolates [39].

In R1, the addition of $1.0 \%$ or $1.5 \%$ of PPCP to raw chicken sausages increased the use-by date from 16 (control) to 22 (T1) and 24 (T2) days, respectively. However, it was not sufficient to guarantee aerobic mesophilic counts below $5 \log \mathrm{cfu} / \mathrm{g}$ during 60 days of storage, which is the printed shelf-life of the product. For this reason, concentrations of PPCP above $1.5 \%$ should be studied, according to the inhibition potential observed in Figure 4 and Figure S1. Additionally, proper management of the cold chain throughout distribution is a suitable strategy to achieve a greater use-by date in this route. As presented in Figure 2, R1 was the route with the highest temperature profile.

In R2, aerobic mesophilic counts below $5 \log \mathrm{cfu} / \mathrm{g}(\mathrm{m})$ were achieved for more than 60 days only by cold chain management, dispensing the addition of any preservative in the product. However, remarkable increases of 55 (T1) and 76 days (T2) were achieved by adding PPCP in sausages. In R3, it was possible to note the importance of adding 
PPCP in sausages. The use-by date increased from 43 days (control) to 69 (T1) and 83 (T2) days, ensuring aerobic mesophilic counts below $5 \log \mathrm{cfu} / \mathrm{g}(\mathrm{m})$ during 60 days of storage (Table 2).

All sample groups showed use-by date below 60 days in semifinished chicken products, regardless of route. These results indicate the positive effect on shelf life due to cold chain management and PPCP. In this sense, the addition of 1.0\% PPCP to seasoned chicken slit back increased the use-by date from 39 to 63 in R2. Only with the addition of PPCP at 1.5\% the use-by date was increased to 124 and 60 days in R2 and R3, respectively (Table 3).

In seasoned chicken thigh, aerobic mesophilic counts below $5 \mathrm{log} \mathrm{cfu} / \mathrm{g}$ were only achieved in R2 with the addition of PPCP at 1.0\% (80 days) and 1.5\% (122 days). These results reinforce the importance of PPCP to extend the use-by date in semifinished chicken products; however, the temperature profile in logistic distribution routes is a crucial factor for product shelf-life extension (Figure S2, Tables 3 and 4).

In the control group, which is the current industry formulation, only $11 \%$ of the chicken products complied the microbiological limit that separates good quality from marginally acceptable quality $(\mathrm{m}=5 \mathrm{log} \mathrm{cfu} / \mathrm{g}$ ) prescribed by regulatory agencies during 60 days of printed shelf-life [8-10]. The percentages increased to 44 and $67 \%$ by adding $1.0 \%$ or 1.5\% of PPCP, respectively (Figure S3). This finding demonstrates that besides delivering postbiotic compounds, PPCP may act as a natural preservative in raw chicken sausages and semifinished chicken products to control aerobic mesophilic below $5 \log \mathrm{cfu} / \mathrm{g}$ during 60 days of cold storage.

Interactions concerning food ingredients and microbes are complex to design in a durability study to estimate use-by dates [40]. Moreover, temperature variations caused by external aspects such as climatic and geographic factors and normal fluctuation over the day may affect microbial growth and impact the food shelf-life period. While some predictive methods allow to carry out a durability study at different temperatures, few methods permit the use of a dynamic temperature profile in the same test to achieve realistic temperature conditions based on the temperatures to which the products are exposed during storage for sale in markets [41]. In the present study, the microbial growth predictor named MicroLab_shelfLife ${ }^{\circledR}$ was designed to perform a durability study of meat products by predicting the microbial growth curve of their natural microbiota under a dynamic temperature profile.

A realistic temperature profile collected in DC and $M$ throughout the $R$ was considered in this study. In addition, a method to perform a durability study of raw chicken sausages and semifinished chicken products by predicting the microbial growth curve of their natural microbiota was used.

\section{Conclusions}

Potentially postbiotic-containing preservative (PPCP) produced by a semiseparated coculture system with L. paracasei DTA 83 and S. boulardii 17 may be a functional natural alternative to extend the use-by date of raw chicken sausages and semifinished chicken products. However, cold chain management throughout logistics is the crucial factor to avoid product spoilage. The present study reveals the impact of the logistics on chicken sausage products spoilage and may be useful for guiding the responsible use of preservatives. Food operators should support the use of preservatives regarding the logistic routes to where the product will pass by. Additionally, the beneficial immunomodulatory responses of PPCP in the host must be further studied in an in vivo model. For the preservative effects, a robust study should be designed to draft the temperature profile in distribution routes to verify failures in the cold chain management that may impact the use-by date of products.

Supplementary Materials: The following supporting information can be downloaded at: https: / / www.mdpi.com/article/10.3390/su14052646/s1, Figure S1. Susceptibility of spoiling chicken product-related microorganisms to potentially postbiotic-containing preservative (PPCP). Figure S2. Impact of temperature profile by the routes R1 (a), R2 (b), and R3 (c) in the use-by date of chicken 
products. Squares represent Mean and bars represent Standard Error. Different letters in the same box indicate a significant difference by Fisher's LSD test at 0.95 of reliability. Figure S3. Percentage of chicken products (raw chicken sausages and semifinished chicken products) in compliance with the minimum limit prescribed by regulatory agencies. (a) no addition of potentially postbioticcontaining preservative (PPCP), (b) $1.0 \%$ of PPCP, and (c) 1.5\% of PPCP. Table S1. Linear regression parameters of the microbial growth of chicken-related contaminants at different concentrations of potentially postbiotic-containing preservative (PPCP). Table S2. Predicted modeling (Baranyi or modified Gompertz's model) to adjust the L. paracasei DTA 83 and S. boulardii 17 growth during fermentation. DMFit software version 3.5 (Institute of Food Research, Norwich).

Author Contributions: Conceptualization, C.L.d.A.G., L.M.C., C.A.G. and A.F.G.; methodology, B.P.d.P.; validation, W.J.F.L.J. and V.d.S.D.; writing-original draft preparation, A.F.G.; writingreview and editing, V.S.d.O.; supervision, R.H.L., I.R.B. and A.F.G. All authors have read and agreed to the published version of the manuscript.

Funding: This research received no external funding.

Institutional Review Board Statement: Not applicable.

Informed Consent Statement: Not applicable.

Data Availability Statement: Not applicable.

Acknowledgments: The authors are grateful to BRC Ingredients (Rio Claro, São Paulo) for sponsoring this research.

Conflicts of Interest: The authors declare no conflict of interest.

\section{Appendix A}

A computational predictive modeling package named MicroLab_ShelfLife ${ }^{\circledR}$ was developed using the Visual Basic for Application-Excel 2016 (MicroSoft, Washington, DC, USA) to serve as an auxiliary tool for laboratory routine to perform a durability study of meat products.

Packages $(n=5)$ from the same batch and manufactured under the same conditions are used to estimate 'use-by' or 'best-before' date using the natural microbiota of the meat products. A borderline limit can be entered in the computational package, based on preliminary studies for the matrix, to preview the 'use-by' or 'best-before' date of the test. The method ISO 4833 (2013) may be used for enumeration of microorganisms in samples [42]. A package $(n=1)$ must be analyzed as soon as the product arrives in the laboratory (time zero). Microbial population in the remained packages $(n=4)$ are stimulated to grow by pair incubation at a lower and a higher temperature. Laboratories can determine the incubation temperatures; however, lower and higher temperatures with a value comprehended from 4 to $20^{\circ} \mathrm{C}$ and 25 to $36^{\circ} \mathrm{C}$ must be used, respectively. Except for the time zero, there is no predefined time for microbial counting once the computational predictive modeling package is able to process any time; however, microbial growth $(\log )$ phase must be included at least in one of the counts. Results related to the colony counting must be entered in the computational predictive modeling package to obtain information about the parameters of the method and the microbial growth curve at a chosen dynamic temperature profile.

\section{Appendix A.1. Growth Phase Modeling}

Specific growth rates per hour $(\log \mathrm{cfu} / \mathrm{g} / \mathrm{h})$ at lower and higher temperatures are obtained by determining the angular coefficient of the microbial growth $(\log )$ phase in each growth curve. They are calculated to one unit of degree Celsius $\left(\log \mathrm{cfu} / \mathrm{g} / \mathrm{h} /{ }^{\circ} \mathrm{C}\right)$ by dividing the mean value of the angular coefficient by the difference between the higher and the lower temperature (Equation (A1)). This parameter is used to calculate the microbial growth per hour at each temperature profile. Hourly microbial growth is obtained by 
multiplying the specific growth rate $\left(\log \mathrm{cfu} / \mathrm{g} / \mathrm{h} /{ }^{\circ} \mathrm{C}\right)$ by the temperature value during $1 \mathrm{~h}$. Daily growth is obtained by the sum of all hourly growth (Equation (A2)):

$$
\begin{gathered}
N(\text { Tgrowth })\left(\log \mathrm{cfu} / \mathrm{g} / \mathrm{h} /{ }^{\circ} \mathrm{C}\right)=\left(\left(\frac{\alpha(H T)-\alpha(L T)}{2}\right) \cdot\left(\frac{1}{H T-L T}\right)\right) / 24 \\
\text { Ngrowth }(\log \mathrm{cfu} / \mathrm{g})=\sum_{k=1}^{24} n \cdot(N(\text { Tgrowth }))
\end{gathered}
$$

where, $N$ (Tgrowth) — rate of microbial growth per degree Celsius (log cfu $\left./ \mathrm{g} / \mathrm{day} /{ }^{\circ} \mathrm{C}\right)$ in the growth (log) phase; $\alpha(H T)$ and $\alpha(L T)$-angular coefficients at the higher (HT) and lower (LT) temperatures $\left({ }^{\circ} \mathrm{C}\right)$, respectively; $n$-hourly temperature ranging from 4 to $36{ }^{\circ} \mathrm{C}$; Ngrowth-daily microbial growth $(\log \mathrm{cfu} / \mathrm{g})$ in the log phase; and $k$-time (hour).

\section{Appendix A.2. Deceleration Phase Modeling}

Correlation variable factor $F T(n)$ (Equation (A3)) was created and inserted in Equations (A1) and (A3) to model the microbial growth in the deceleration phase based on the value of the log phase (Equations (A4) and (A5)). The ratio of the log and deceleration phases period was determined at four different temperatures $\left(4,12,24\right.$, and $\left.36{ }^{\circ} \mathrm{C}\right)$, and xy-scatter charts were plotted with log/deceleration values (coordinate abscissa) and incubation temperature (axial abscissa). Linear regression was used for mathematical modeling of values. To determine the variable factor $F T(n)$ for any temperature profile, the average daily temperature was calculated, and the first-degree equation was considered:

$$
\begin{gathered}
F T(n)=L / D \\
N\left(\text { Tdeceleration) }\left(\log \mathrm{cfu} / \mathrm{g} / \mathrm{h} /{ }^{\circ} \mathrm{C}\right)=N(\text { Tgrowth }) / F T(n)\right. \\
\text { Ndeceleration }(\log \mathrm{cfu} / \mathrm{g} / \mathrm{dia})=\sum_{k=1}^{24} n \cdot(N(\text { Tdecedeleration })) / F T(n)
\end{gathered}
$$

where $N$ (Tdeceleration) - microbial growth rate per degree Celsius $\left(\log \mathrm{cfu} / \mathrm{g} / \mathrm{day} /{ }^{\circ} \mathrm{C}\right)$ in the deceleration phase; $N($ Tgrowth) — microbial growth rate per degree Celsius (log $\mathrm{cfu} / \mathrm{g} /$ day $/{ }^{\circ} \mathrm{C}$ ) in the $\log$ phase; $F T(n)$ — correlation variable factor to describe specific growth rate between $\log$ and deceleration phases per degree Celsius; $n$-hourly temperature ranging from 4 to $36{ }^{\circ} \mathrm{C}$; Ndeceleration-daily microbial growth $(\log \mathrm{cfu} / \mathrm{g})$ in the deceleration phase; and $k$-time (hour).

\section{References}

1. Barcenilla, C.; Ducic, M.; López, M.; Prieto, M.; Álvarez-Ordóñez, A. Application of lactic acid bacteria for the biopreservation of meat products: A systematic review. Meat Sci. 2022, 183, 108661. [CrossRef]

2. Yusuf, M. Chapter 12-Natural Antimicrobial Agents for Food Biopreservation. In Handbook of Food Bioengineering; Grumezescu, A.M., Holban, A.M., Eds.; Academic Press: Cambridge, MA, USA, 2018; pp. 409-438. ISBN 978-0-12-811516-9.

3. Rajanikar, R.V.; Nataraj, B.H.; Naithani, H.; Ali, S.A.; Panjagari, N.R.; Behare, P.V. Phenyllactic acid: A green compound for food biopreservation. Food Control 2021, 128, 108184. [CrossRef]

4. Mun, S.Y.; Kim, S.K.; Woo, E.R.; Chang, H.C. Purification and characterization of an antimicrobial compound produced by Lactobacillus plantarum EM showing both antifungal and antibacterial activities. LWT 2019, 114, 108403. [CrossRef]

5. Bouju-Albert, A.; Pilet, M.-F.; Guillou, S. Influence of lactate and acetate removal on the microbiota of French fresh pork sausages. Food Microbiol. 2018, 76, 328-336. [CrossRef]

6. Liu, X.; Basu, U.; Miller, P.; McMullen, L.M. Differential gene expression and filamentation of Listeria monocytogenes 08-5923 exposed to sodium lactate and sodium diacetate. Food Microbiol. 2017, 63, 153-158. [CrossRef]

7. Argyri, A.A.; Panagou, E.Z.; Nychas, G.-J.E. 7-Advances in vacuum and modified atmosphere packaging of poultry products. In Advances in Mea, Poultry and Seafood Packaging; Kerry, J.P., Ed.; Woodhead Publishing: Cambridge, UK, 2012; pp. 205-247; ISBN 978-1-84569-751-8.

8. EFSA. Regulation (EC) No 1333/2008 of the European Parliament and of the Council of 16 December 2008 on food additives. Off. J. Eur. Union 2008, 336, 16-33.

9. ANVISA. Instrução normativa n 60, de 23 de dezembro de 2019. Diário Oficial da União 2019, 41, 133. 
10. ANVISA. Resolução de Deretoria Colegiada n ${ }^{\circ}$ 331, de 23 de dezembro de 2019. Diário Oficial da União 2019, 4, 96.

11. Zommiti, M.; Feuilloley, M.G.J.; Connil, N. Update of probiotics in human world: A nonstop source of benefactions till the end of time. Microorganisms 2020, 8, 1907. [CrossRef]

12. Catania, J.; Pandit, N.G.; Ehrlich, J.M.; Zaman, M.; Stone, E.; Franceschi, C.; Smith, A.; Tanner-Smith, E.; Zackular, J.P.; Bhutta, Z.A.; et al. Probiotic supplementation for promotion of growth in children: A systematic review and meta-analysis. Nutrients 2022, 14, 83.

13. FAO/WHO. Guidelines for the Evaluation of Probiotics in Food; FAO: Rome, Italy, 2002; p. 11.

14. Taverniti, V.; Guglielmetti, S. The immunomodulatory properties of probiotic microorganisms beyond their viability (ghost probiotics: Proposal of paraprobiotic concept). Genes Nutr. 2011, 6, 261-274. [CrossRef] [PubMed]

15. Deshpande, G.; Athalye-Jape, G.; Patole, S. Para-probiotics for preterm neonates-The next frontier. Nutrients $2018,10,871$. [CrossRef] [PubMed]

16. Siciliano, R.A.; Reale, A.; Mazzeo, M.F.; Morandi, S.; Silvetti, T.; Brasca, M. Paraprobiotics: A new perspective for functional foods and nutraceuticals. Nutrients 2021, 13, 1225. [CrossRef]

17. Tsilingiri, K.; Barbosa, T.; Penna, G.; Caprioli, F.; Sonzogni, A.; Viale, G.; Rescigno, M. Probiotic and postbiotic activity in health and disease: Comparison on a novel polarised ex-vivo organ culture model. Gut 2012, 61, 1007-1015. [CrossRef] [PubMed]

18. Shenderov, B.A. Metabiotics: Novel idea or natural development of probiotic conception. Microb. Ecol. Health Dis. 2013, 24, 20399. [CrossRef]

19. İncili, G.K.; Karatepe, P.; Akgöl, M.; Güngören, A.; Koluman, A.; İlhak, O.İ.; Kanmaz, H.; Kaya, B.; Hayaloğlu, A.A. Characterization of lactic acid bacteria postbiotics, evaluation in-vitro antibacterial effect, microbial and chemical quality on chicken drumsticks. Food Microbiol. 2022, 104, 104001. [CrossRef]

20. Requena, T.; Pérez Martínez, G. 3.14-Probiotics, Prebiotics, Synbiotics, Postbiotics and Other Biotics. What's Next? In $A$ Comprehensive Gut Microbiota; Glibetic, M., Ed.; Elsevier: Oxford, UK, 2022; pp. 197-210. ISBN 978-0-12-822036-8.

21. Anhê, F.F.; Bhatwa, A.; Schertzer, J.D. Determining the metabolic impact of postbiotics in mice. STAR Protoc. $2022,3,101098$. [CrossRef]

22. ANVISA. Resolução de Diretoria Colegiada n 272 de 14 de março de 2019. Diário Oficial da União 2019, 35, 194.

23. Lemos Junior, W.J.F.; Guerra, A.F.; Tarrah, A.; Duarte, V.S.; Giacomini, A.; Luchese, R.H.; Corich, V. Safety and stability of two potentially probiotic Lactobacillus strains after in vitro gastrointestinal transit. Probiotics Antimicrob. Proteins 2020, 12, 657-666. [CrossRef]

24. Guerra, A.F.; Lemos Junior, W.J.F.; Santos, G.O.; Andrighetto, C.; Giacomini, A.; Corich, V.; Luchese, R.H. Lactobacillus paracasei probiotic properties and survivability under stress-induced by processing and storage of ice cream bar or ice-lolly. Ciência Rural 2018, 48, 1-9. [CrossRef]

25. Lemos Junior, W.J.F.; Guerra, A.F.; Duarte, V.S.; Treu, L.; Tarrah, A.; Campanaro, S.; Luchese, R.H.; Giacomini, A.; Corich, V. Draft genome sequence data of Lactobacillus paracasei strain DTA 83 isolated from infant stools. Data Br. 2019, 22, 1064-1067. [CrossRef]

26. Laureano-Melo, R.; Caldeira, R.F.; Guerra, A.F.; Conceição, R.R.D.; Souza, J.S.D.; Giannocco, G.; Marinho, B.G.; Luchese, R.H.; Côrtes, W.S. Maternal supplementation with Lactobacillus paracasei DTA 83 alters emotional behavior in Swiss mice offspring. PharmaNutrition 2019, 8, 100148. [CrossRef]

27. Tarrah, A.; Duarte, V.S.; Castilhos, J.; Pakroo, S.; Lemos Junior, W.J.F.; Luchese, R.H.; Guerra, A.F.; Rossi, R.C.; Righetto Ziegler, D.; Corich, V.; et al. Probiotic potential and biofilm inhibitory activity of Lactobacillus casei group strains isolated from infant feces. J. Funct. Foods 2019, 54, 489-497. [CrossRef]

28. Silva, L.C.; Schmidt, G.B.; Alves, L.G.O.; Oliveira, V.S.; Laureano-Melo, R.; Stutz, E.; Martins, J.F.P.; Paula, B.P.; Luchese, R.H.; Guerra, A.F.; et al. Use of probiotic strains to produce beers by axenic or semi-separated co-culture system. Food Bioprod. Process. 2020, 124, 408-418. [CrossRef]

29. Silva, L.C.; Lago, H.S.; Rocha, M.O.T.; Oliveira, V.S.; Laureano-Melo, R.; Stutz, E.T.G.; Paula, B.P.; Martins, J.F.P.; Luchese, R.H.; Guerra, A.F.; et al. Craft beers fermented by potential probiotic yeast or lacticaseibacilli strains promote antidepressant-like behavior in swiss webster mice. Probiotics Antimicrob. Proteins 2021, 13, 698-708. [CrossRef]

30. Oliveira, W.A.; Rodrigues, A.R.P.; Oliveira, F.A.; Oliveira, V.S.; Laureano-Melo, R.; Stutz, E.T.G.; Lemos Junior, W.J.F.; Paula, B.P.; Esmerino, E.A.; Corich, V.; et al. Potentially probiotic or postbiotic pre-converted nitrite from celery produced by an axenic culture system with probiotic lacticaseibacilli strain. Meat Sci. 2021, 174, 108408. [CrossRef]

31. Alcine Chan, M.Z.; Chua, J.Y.; Toh, M.; Liu, S.-Q. Survival of probiotic strain Lactobacillus paracasei L26 during co-fermentation with S. cerevisiae for the development of a novel beer beverage. Food Microbiol. 2019, 82, 541-550. [CrossRef]

32. Shao, L.; Tian, X.; Yu, Q.; Xu, L.; Li, X.; Dai, R. Inactivation and recovery kinetics of Escherichia coli O157:H7 treated with ohmic heating in broth. LWT 2019, 110, 1-7. [CrossRef]

33. Paula, B.P.; Chávez, D.W.H.; Lemos Junior, W.J.F.; Guerra, A.F.; Corrêa, M.F.D.; Pereira, K.S.; Coelho, M.A.Z. Growth parameters and survivability of Saccharomyces boulardii for probiotic alcoholic beverages development. Front. Microbiol. 2019, 10, 2092. [CrossRef]

34. Paula, B.P.; Lago, H.S.; Firmino, L.; Lemos Júnior, W.J.F.; Corrêa, M.F.D.; Guerra, A.F.; Pereira, K.S.; Coelho, M.A.Z. Technological features of Saccharomyces cerevisiae var. boulardii for potential probiotic wheat beer development. LWT 2021, 135, 110233. [CrossRef]

35. Associação Brasileira de Proteína Animal. Protocolo de Bem-Estar para Frangos de Corte. Available online: http://www.abpa-br. org (accessed on 3 February 2022). 
36. ISO 4833-1; Microbiology of the Food Chain-Horizontal Method for the Enumeration of Microorganisms—Part 1: Colony Count at 30 Degrees $C$ by the Pour Plate Technique. ICS: Washington, DC, USA, 2013.

37. Moradi, R.; Nosrati, R.; Zare, H.; Tahmasebi, T.; Saderi, H.; Owlia, P. Screening and characterization of in-vitro probiotic criteria of Saccharomyces and Kluyveromyces strains. Iran. J. Microbiol. 2018, 10, 123-131. [PubMed]

38. Stanojević-Nikolić, S.; Dimić, G.; Mojović, L.; Pejin, J.; Djukić-Vuković, A.; Kocić-Tanackov, S. Antimicrobial activity of lactic acid against pathogen and spoilage microorganisms. J. Food Process. Preserv. 2016, 40, 990-998. [CrossRef]

39. Halstead, F.D.; Rauf, M.; Moiemen, N.S.; Bamford, A.; Wearn, C.M.; Fraise, A.P.; Lund, P.A.; Oppenheim, B.A.; Webber, M.A. The antibacterial activity of acetic acid against biofilm-producing pathogens of relevance to burns patients. PLoS ONE 2015, 10, e0136190. [CrossRef]

40. Angulo, M.T.; Moog, C.H.; Liu, Y.-Y. A theoretical framework for controlling complex microbial communities. Nat. Commun. 2019, 10, 1045. [CrossRef]

41. Conte-Junior, C.A.; Monteiro, M.L.G.; Patrícia, R.; Mársico, E.T.; Lopes, M.M.; Alvares, T.S.; Mano, S.B. The effect of different packaging systems on the shelf life of refrigerated ground beef. Foods 2020, 9, 495. [CrossRef] [PubMed]

42. Food Safety Authority of Ireland. Guidande Note No. 18 Validation of Product Shelf-Life, 4th ed.; Food Safety Authority of Ireland: Dublin, Ireland, 2019. 